\title{
Political Contextuality of Martin McDonagh's Hangmen: An Intervention in the Debate over Capital Punishment in Britain
}

\author{
Martin McDonagh'ın Hangmen Oyununun Politik Bağlamsallığı: \\ İngiltere'de İdam Cezası Tartışmalarına Bir Müdahale \\ Özlem ÖZMEN*
}

\begin{abstract}
Martin McDonagh's Hangmen (2015) is a contextual play as the work derives its material from an actual historical event, the abolition of capital punishment in the 1960s, and presents this topic in 2015 soon after the debates of reintroducing death penalty in Britain. The play refers to two distinct socio-historical backgrounds, 1960s Britain as the context of the plot, and the twenty-first century as the context of the audience/reader. Hangmen takes place on a very specific date in history, the year in which hanging was suspended in Britain. The comical portrayal of what seems to be the last hanging case in the country makes it possible to problematise the integrity of the judicial system at the time. Presentation of the rivalry between two famous executioners in the country, Harry Allen and Albert Pierrepoint, also underlines the play's socio-political relation to a certain context. What is equally noteworthy about Hangmen is McDonagh's choice of this topic at a time in which the issue of capital punishment is raised again in Britain. Concerning recent arguments about the reintroduction of death penalty, it is observed that McDonagh also initiates a discussion about the legitimation of state violence through a depiction of the history of hanging. In light of this observation, the aim of this article is to discuss McDonagh's topical dark comedy as a political intervention in the debate over death penalty in Britain by mentioning the correlation between the play and appropriate case studies of several hanging offences in the history of Britain.
\end{abstract}

Keywords: Martin McDonagh, Hangmen, relational, contextual, capital punishment, death penalty.

$\ddot{O} \mathbf{z}$

Martin McDonagh'ın Hangmen (2015) adlı oyunu, konusunu 1960'larda idam cezasının kaldırılması gibi gerçek bir tarihî olaydan alması ve aynı konuyu 2015'te bu cezanın yeniden getirilmesi tartışmalarının ardından işlemesi bakımından tarihsel bağlamı olan bir oyundur. Oyun, konusunun geçtiği 1960'lar İngiltere'sine ve okuyucunun/seyircinin içinde bulunduğu yirmi birinci yüzyıla, yani birbirinden uzak iki farklı sosyal ve tarihî döneme gönderme yapmaktadır. Hangmen, İngiltere'nin geçmişinde çok belirli bir tarih olan idam cezasının kaldırıldığı yılda geçmektedir. Komik bir biçimde ülkedeki son idam cezası olarak gösterilen olay, bu dönemdeki adalet sisteminin doğruluğunu sorgulamayı mümkün kılmaktadır. Bu dönemde ülkenin meşhur iki infazcısı olan Harry Allen ve Albert Pierrepoint'in oyunda karakterler olarak kullanılması ve aralarındaki rekabetin gösterilmesi de yine oyunun belirli bir döneme gönderme yaptığını göstermektedir. Bu oyunla ilgili eşit derecede önemli olan bir diğer konu ise McDonagh'nın bu konuyu işlemeyi İngiltere'de idam cezasının yeniden getirilmesinin gündemde olduğu bir zamanda seçmiş olmasıdır. Son yıllarda ölüm cezasının yeniden getirilmesi konusundaki güncel tartışmalar düşünüldüğünde, Martin McDonagh, bu oyunuyla geçmişten bir olayı göstererek aynı zamanda devlet destekli şiddetin meşrulaştırılması konusunda bir tartışmaya girmektedir. Bu gözlem ışı̆̆ında bu makalenin amacı, McDonagh'ın gündemle ilişkili olan bu kara mizahı ve İngiltere tarihindeki gerçek idam cezası vakaları arasındaki bağlantıyı konu edinerek Hangmen oyununu ülkedeki idam tartışmalarına siyasî bir müdahale olarak tartışmaktır.

Anahtar Kelimeler: Martin McDonagh, Hangmen, bağlamsal, idam cezası, ölüm cezası.

\section{Introduction}

As an Irish dramatist and screenwriter, Martin McDonagh is mostly known for representing Irish culture, Irish nation and Irish politics in his works. His works are popular for their dark humour, and their political content is not always in the foreground in scholarly discussion. His most recent play Hangmen (2015) challenges this notion as the play, this time, is not about Ireland but a very specific part of North England, Oldham, and it deals with capital punishment as a political issue. This work is, like most of his other plays, a comedy; however, almost farcical comedy elements of the play do not prevent it from being a political commentary on a serious issue in British history. McDonagh's plays are mostly comedies ingrained

\footnotetext{
* Assist. Prof. Dr., Muğla Sitkı Koçman University, Faculty of Letters and Humanities, Translation and Interpreting Department, ozlemozmen@mu.edu.tr
}

Özmen, Ö. (2019). Political Contextuality of Martin McDonagh's Hangmen: An Intervention in the Debate over Capital Punishment in Britain, Gaziantep University Journal of Social Sciences, 18 IDEA Special Issue, 92-101, Submission Date: 31-07-2019, Acceptance Date: 30-12-2019.

Araştırma Makalesi. 
with too much violence. Therefore, it would be an injustice to consider them as pure comedies due to their equally important violent nature. He utilises comedy or elements of comedy for an entirely different purpose, to awaken the audience to the grim realities of their sociocultural context, and to point out the everlasting presence of cruelty in their world. As such, comedy elements in Hangmen are functional in terms of criticising institutional violence and problematising the integrity of the judicial system. So far, the play has been discussed by scholars like Ondřej Pilný, José Lanters, and Joan FitzPatrick Dean. In two respective articles, Pilný compares Hangmen with McDonagh's previous works and claims that the play marks a deviation in the dramatist's style as it is based on real historical figures, and it deals with an important political issue till the end $(2018$, p. 91; 2017, p. 121). Drawing attention to the political underpinnings of the play in a similar vein, FitzPatrick Dean asserts that the play functions as a message play for the contemporary audience despite the playwright's intentions (2018, p. 101). This article shares a common ground with these studies as it underlines that the use of real historical figures as characters in the play is a different stylistic approach in McDonagh's drama, and furthermore discusses McDonagh's topical dark comedy as a political intervention in the debate over death penalty in Britain regarding its references to the unlawful hanging offences in the history of Britain. It this analysis, Hangmen is analysed as a social realist play which takes its material from the 1960s Britain and speaks to its own context. With this approach, the article aims to initiate a discussion concerning whether McDonagh's drama is moving toward a more overtly politicised direction than before.

Hangmen is a historical comedy dealing with the abolition of capital punishment in Britain. The play premiered at Royal Court Theatre in 2015 and soon was transferred to the West End to be staged at Wyndham's Theatre in 2016. The play received great acclaim by audiences and critics alike who were pleased to see that the danger of state violence as a current issue was addressed with a satirical treatment of what is portrayed to be a historical issue. Susannah Clapp notes in The Guardian that Hangmen, with its direct engagement with a crucial topic, marks a departure in McDonagh's drama career after twelve years of absence (2015, para. 2). Michael Billington emphasises the play's representation of the perspectives of famous executioners after their profession has become illegal (2015, para. 1). In The Telegraph, Dominic Cavendish also observes the change of McDonagh's style in this play and expresses that he expects the play to be rightfully transferred to the West End (2015, para. 7). Contrary to these positive remarks about McDonagh's play, Aleks Sierz criticises the play for its weak characterisation noting that Harry lacks motivation as the protagonist of the play and a famous executioner in the history of Britain (Pilný, 2018, p. 97). A common aspect of these reviews is their stress on the increased political tone of McDonagh's drama, which will be elaborated in this study.

At the start of the play, a fictional so-called criminal James Hennessy is executed by force by Harry Allen, a famous hangman in the 1960s. This scene portrays what is known as the last hanging case in the country. Following this execution, subsequent scenes demonstrate Harry Allen's pub which he runs as he has lost his job due to the abolition of death penalty in the country. The play's note about the futility of capital punishment is primarily given with Mooney, a character who comes to Harry's pub as a menacing person, and is accidentally killed by Harry who wants to punish him for allegedly kidnapping his daughter Shirley. As a common structural aspect of Martin McDonagh's plays, Mooney acts as a character appearing at the end of the play that is used to indicate the uselessness of violence to the audience. His accidental death marks an important moment in the play as the integrity of justice is scrutinised with his unlawful killing, and former hangman Harry, who always prides himself on carrying out justice, ironically turns into a criminal figure. The vanity of Mooney's death is 
indicated with the arrival of Harry's daughter Shirley as it turns out that Mooney actually did not kidnap her, and he shouldn't have been killed. The irony in the ending is possibly the strongest element of dark humour in the play as the futility of punishing individuals is conveyed with this final killing. Considering this scene as a dark note on the uselessness of violence and blind adherence to ideals of justice, Mooney's accidental killing should not only be seen as an element of dark humour but a political comment on various actual public punishment cases in Britain that have been carried out wrongfully.

The inadvertent death of Mooney at the end of the play is as problematic as the initial execution of James Hennessy at the beginning. As Mooney's death is so sudden and random, the reliability of justice in James Hennessy's execution is also inevitably questioned. There is an emphasis in the play on the fact that these two characters are killed by Harry with the same "billyclub" (McDonagh, 2015, p. 13), which leads to handling these two cases comparatively. Hennessy is presented as the last executed man in the country while Mooney's death is presented as unlawful as it takes place after the abolition of hanging. The fact that both these men are killed by Harry with the same tool in a violent manner sparks the question of whether James Hennessy's death could also be unlawful as Mooney's rather than a service paid to the law as Harry asserts. The certainty of Mooney's death as an accident renders James Hennessy's case as a dubious one as it reveals that he is most probably hanged for no obvious crime but upon suspicion. Hennessy's death is suspicious as he was hanged for no obvious crime but upon speculation. It can only be assumed that he is charged with sexual abuse, however, there is no certain evidence for his involvement in the mentioned crime other than Harry's strong claim that he is a "classic woman-hating psychopath" (McDonagh, 2015, p. 39). As this issue is never revealed openly throughout the play, the absurdity of his rush killing is highlighted with Mooney's death. The play's demonstration of such dubious hanging cases makes it possible to consider the real controversial cases of execution carried out under the name of the criminal justice system. Although McDonagh's intention is not to convey a political message to the audience as he says "I really didn't want it to be a message play" (as cited in O'Hagan, 2015, para. 2), the use of real historical figures as characters in the play and allusions to a certain historical context help reveal its political undertones.

McDonagh's play is related to two historical contexts, the 1960s as the historical background of the characters in the play, and 2015 as the context of the audience. Political ideas of the play are actually resonant with both of these historical milieux. The play portrays the early 1960s in the first scene where James Hennessy is hanged and moves on to present the years following 1965 when hanging was abolished ending its four-century long practice. The abolition of death penalty has often been considered as part of other liberalising reforms in 1960s Britain. Along with some other reforms such as Sexual Offences Bill and Abortion Act in 1967, and the repelling of censorship in 1968, the abolition of death penalty is also considered as a product of the "permissive society" as Britain came to be known in those years (Lowe, 2017, p. 486). The play is not only political as it reflects this very specific moment in history but it particularly employs characters some of which are based on real-life figures for which Ondřej Pilný regards the play as "a turn in his [McDonagh's] career" (2018, p. 91). The two most important characters, the "hangmen" of the play are based on the two most popular executioners in British history, Albert Pierrepoint and Harry Allen whose name is transformed in the play into Harry Wade. Apart from these famous executioners, several other people are also mentioned in the play whose names have been involved in miscarriages of justice. Representation of real people who are somehow related to capital punishment or remembering some of the innocent people who have been wrongfully killed indicates that the play provides a commentary on the problematic aspects of justice in criminal law. 
Considering the 1960s as the dominant context of the play, it needs to be noted that hanging was then a popular profession in Britain. There is a long list of popular hangmen in the history of Britain, and it is possible to learn about their profession from their diaries including former hangmen John Ellis' Diary of a Hangmen (1996), Syd Dernley and David Newman's The Hangman's Tale (1990), and the best-known exponent Albert Pierrepoint's Executioner: Pierrepoint (1990) (Campbell, 2015, p. 16). The popularity of these figures also continued with some movies talking about their stories. For example, Albert Pierrepoint's popularity increased with the 2005 movie titled Pierrepoint: The Last Hangman. Albert Pierrepoint's popularity was initially established as a "wartime executioner" (Fielding, 2008, p. iii) since it is known that he executed a lot of Nazi war criminals, a fact that is also mentioned in McDonagh's play. Subsequent movies and books talking about his life also contributed to his fame as the most famous executioner in the history of Britain. For Albert Pierrepoint, hanging was a family profession since his father and his uncle were also wellknown hangmen. As Stephen Wade (2009) mentions the celebrity of the Pierrepoint family in his diary:

The Pierrepoint dynasty of hangmen undoubtedly created a great deal of professionalism and pride in their work; Albert is the one from the family whose career has had the most prominence in the media and in biography, and one aspect of that long career that needs to be stressed is that he withstood a huge amount of pressure in all kinds of contexts, from the war crimes work to his responses give to commissions on capital punishment (p. 102).

Although Albert Pierrepoint is the number one hangman in British history, Martin McDonagh uses him as a side character in his play. His central character Harry Wade is based on the second-best hangman in the country, Harry Allen. ${ }^{1}$

Like Pierrepoint, Harry Allen was also a public figure. ${ }^{2}$ McDonagh's depiction of Harry is close to the experiences of real-life executioner Harry Allen to a considerable extent. In line with his representation in the play, the reports suggest that Harry Allen, in real life, "always wore a black bow tie at executions and two of these were sold in November 2008 along with other items, including his diary" (Clark, 1995a). Even the pub setting in Hangmen is a projection of the executioner Harry's actual profession after the abolition of hanging in Britain. Interestingly enough, both these popular executioners, Albert Pierrepoint and Harry Allen, opened a pub following the abolition of death penalty. It is informed that "[1]ike Albert [whose pub was ironically called "Help the Poor Struggler"], Harry Allen was also a publican, keeping a pub called the Rope and Anchor in Farnworth on the outskirts of Bolton" (Clark, 1995a). Evidently, McDonagh's depiction of these two hangmen is based on historical research. Through a portrayal of these hangmen and allusions to the executed people in British history, the play questions whether being a hangman was really an honourable profession as was often thought, and whether the victims were rightfully judged.

The play's note on the uselessness of capital punishment is mostly observed with references to the cases of wrongfully executed people in the recent past. In his interview with Harry, journalist Clegg in the play mentions the real names of formerly executed people whose cases still retain their controversial nature. Research into the stories of these people reveals that all their cases are contestable and that most probably they were innocent of the crimes they were charged with. Among these names, a man called Derek Bentley was hanged in 1953 for the murder of a policeman despite the fact that he was not really guilty of the

\footnotetext{
${ }^{1}$ Actually, the character's full name is a mixture of two famous hangmen in history, Harry Allen and Stephen Wade.

${ }^{2}$ The fact that Harry Allen's wax effigy is displayed in the Chamber of Horrors at Madame Tussauds in London is a strong enough evidence to indicate his celebrity.
} 
crime. As it is reported, the real responsible figure, Chris Craig "was spared because he was under age" (Campbell, 2015, p. 17), which resulted in Bentley's execution instead of him. ${ }^{3}$ It is stated in Stewart McLaughlin's biography Britain's Last Hangman (2008) that Derek Bentley's hanging was the only one Harry Allen regretted, and Bentley's family secured him a posthumous pardon years later (Campbell, 2015, p. 17). Therefore, Clegg's reference to Derek Bentley functions as a reminder of one of the many cases of miscarriage of justice in the judicial system. Another reference to a controversial hanging case concerns mentally challenged Timothy Evans who was killed upon an ambiguous conviction that he killed his pregnant wife. Years after he was killed, it was revealed that the criminal was actually his neighbour called John Reginald Christie. As in the case of Derek Bentley, Timothy Evans was pardoned several years after his hanging. Another reference to an unlawful killing in the play is that of Ruth Ellis who was hanged upon killing her boyfriend who had been abusing her for long years. Ellis' case still remains a problematic and popular one. ${ }^{4}$ Unlike Bentley and Evans, Ellis has not been cleared yet; however, it is certain that her case has widely aroused public attention against punishment by hanging in Britain. Apart from these people, Clegg also mentions the name of James Hennessy, the first executed character in the first scene of the play. There is a striking similarity between his name and that of a real criminal James Hanratty whose case remains one of the most controversial capital punishment cases in Britain. Convicted of murder and rape, Hanratty was hanged in 1962. Different from the other cases, Hanratty's innocence has never been proven; however, his punishment reflects the conflict between the abolitionists and retentionists at the time, and it also demonstrates how the left and the right political groups differed in their approach to the issue of capital punishment. Concerning Hanratty's case, it is stated that " $[\mathrm{b}] \mathrm{y}$ the 1960's the death penalty was increasingly a political issue. The establishment and those on the right believed in it and were insistent on Hanratty's guilt, whereas the liberal left were convinced that he must be innocent" (Clark, 1995b). ${ }^{5}$ Such references in McDonagh's play initiate a discussion concerning the futility of capital punishment by drawing attention to the stories of wrongfully executed people by state violence. Evidently, McDonagh uses this problematic issue as a backdrop to his plot and points to the need to find out whether James Hanratty was really guilty of the crime or not. However, he does not make a final remark about this issue as he leaves the case of his character Hennessy, who represents James Hanratty, unanswered in the play. The audience does not learn whether he was really guilty of the crime he was charged with at the beginning of the play. The dubiousness of his situation leads to question whether his death is only one of the examples of the unlawful killings of innocent people at the time. Juxtaposing the serious tone around the punishment of these victims with the funnily absurd attachment of the hangmen to their professions, McDonagh problematises the irrevocability of unfair capital punishment cases.

Besides these names already mentioned in the play, there were other hanging offences in the criminal history of Britain that need to be remembered to evaluate McDonagh's critical point. The last two men who were simultaneously executed in Britain were Gwynne Evans at Strangeways Prison in Manchester and Peter Allen at Walton gaol in Liverpool in 1964. These two men were convicted for murdering a van driver called John Alan West. It has never been revealed which one of these men was actually responsible for West's death, but both were held responsible and killed anyway. McDonagh's play does not include these two fig-

\footnotetext{
${ }^{3}$ This story might sound familiar for those who have seen the 1991 movie Let Him Have It (Campbell, 2015, p. 17).

${ }^{4}$ It was also adapted into a movie titled Dance with a Stranger (1985).

${ }^{5}$ The popularity and controversy of this occasion also led the incident to be reflected in the movie Hanratty: The Whole Truth in 2002.
} 
ures; however, the portrayal of the last hanging case in the country, and allusions to some other miscarriages of justice also shed light on the controversy behind the execution of these two people. Regarding the case of these two men, Guardian writer, Caroline Davies suggests that "Evans, 24, and Allen, 21, were unlucky with their timing. Two months after they were executed Labour came to power, bringing a Commons vote to suspend capital punishment for five years in the 1965 Murder Act" (2014, para. 5). Apart from demonstrating the opposing views of the political parties to death penalty, this also indicates that these men were most probably hanged without a certain conviction. As a writer, Martin McDonagh is almost always interested in demonstrating the absurdity of violence and the futility of crime. Although it is not possible to form a connection between the characters Hennessy and Mooney in McDonagh's play with Evans and Allen, the suspicious nature of these cases allows questioning whether justice could explain the death of these people. Although McDonagh's play does not directly refer to these people, it is possible to draw a parallelism between his fictional portrayal of state violence and the lack of justice in these actual hanging cases. The examples provided in the play all problematise the humane aspect of the practice as to whether hanging was necessarily used to maintain order and acted as a deterrent to the rest of the society, or it was simply used as a justified way of social cleansing.

All these cases of capital punishment, mentioned or unmentioned in the play, led to a controversy among the public concerning the issue of abolition in the 1960s. Following the abolition of death penalty, while a large number of people still remained pro-hanging for a long time, a lot of people protested against the practice of capital punishment. As Neville Twitchell suggests, "[t]hough the trend was towards abolition, even by 1964-65 there was still a majority for hanging" (2009, p. 14). Two groups represented these opposing views at the time. National Campaign for the Abolition of Capital Punishment (NCACP) was established to change public opinion and to invite politicians to abolish hanging. Problematic aspects of capital punishment were addressed by such groups that advocated the idea that death penalty does not always guarantee justice and that it might lead to irremediable consequences. As Christie Davies explains this contrarian view, "there was and there is no really decisive proof that capital punishment was or is a greater deterrent to murder than all the possible alternative punishments" (2007, p. 44). In time, more people recognised death penalty as "the state's authority and monopoly ... . which extends to power over life and death of its citizens" (Seal, 2014, p. 9). On the political level, in 1969, Labour Prime Minister James Callaghan and Home Secretary William Ross also underlined the moral problem behind death penalty with these words: "We think that those who advocate capital punishment are under the onus of establishing that this barbarous penalty is a unique deterrent; but there is no conclusive evidence, either here or elsewhere, to support such a contention" (as cited in Wright, 2014, p. 8). Despite this rising rejection of capital punishment, some groups like the Sandys, on the other side, led the retentionists (Twitchell, 2009, p. 300) who supported the practice of capital punishment to maintain public security or because of their ideological adherence to authoritarianism. All characters in McDonagh's play are pro-hanging as especially observed in the attitudes of the two hangmen who proudly assume they serve justice and also in the response of the public members at Harry's pub who are ardently keen on hearing another execution story. In this respect, McDonagh does not represent the abolitionist view to display the amount of support for capital punishment and how it was mythologised by the public. Clearly, death penalty has often been an acceptable form of punishment, and changing public opinion against its practice has not always been that easy. As it is stated in the Gallup International Public Opinion Polls: 
As late as 1960, seventy-three percent of the public believed that abolishing the death penalty would increase the crime rate. When a five-year trial period for abolition drew to a close in 1968, a majority still supported capital punishment. A few years after abolition, in 1973, sixty-six percent still thought that death was an acceptable form of punishment (as cited in Tomlinson, 2006, pp. 21-22).

McDonagh's play does not represent real political figures but makes its stance clear on the oppositional side in the case of capital punishment by portraying how it was blindly supported by a large group of people. The play characterises the spirit of the time through a portrayal of the two rival hangmen Harry and Pierrepoint, and common folk that represents the retentionists and idealises executioners for carrying out the so-called justice. The main hangman Harry, for instance, does not seem to accept that "death penalty never worked as a deterrent" (McDonagh, 2015, p. 40) despite Clegg's efforts to make him accept the futility of capital punishment. When Clegg mentions the names of wrongfully executed people, Harry readily blames all such miscarriages of justice on the other hangman Pierrepoint. Presentation of the rivalry between the two ardent hangmen in McDonagh's play is an example of dark humour and functions as a criticism of blind ideological commitment. As it is revealed in the interview between Clegg and Harry, Harry has counted all the executions he has carried out as two hundred and thirty-three while Clegg provokes him by claiming that "Pierrepoint's runs into the six hundreds" (McDonagh, 2015, p. 38). It is seen both in historical records and McDonagh's play that Harry and Pierrepoint were against the abolition of hanging. According to the records, Albert Pierrepoint "took great pride in his work and calculated the drops most carefully - he is said never to have had a single bungled hanging" (Clark, 1995a). Projecting this real image, McDonagh's Harry Allen is also arrogant about his profession and he has become inured to violence, which is presented with his appetite for breakfast after hanging Hennessy, hence enhancing the dark humour of the play. Additionally, his cold-blooded and violent attitude in both hanging cases in the play also demonstrates his willingness to execute institutional violence. The fact that he uses violence towards his victims leads one to question his real motivation: Is he carrying out the criminal law, or does he take pleasure out of killing guilty people? This question gets even stronger as he mentions hanging as peculiarly English in his interview in the play. In a remarkably absurd statement, Harry suggests that among punishment practices, electric chair is from Arkansas and guillotine is French while he sees hanging as specifically proper for the English (McDonagh, 2015, p. 36). This association between hanging as a punishment and England as a nation begs for attention in terms of defining the comedy of the play as a political one. By portraying a character that sees hanging as a national heritage in need of protection, McDonagh points to the absurdity of ideological commitment.

McDonagh's criticism of blindly supporting death punishment is also observed in his portrayal of minor characters or "the cronies" as they are called in the play. The cronies are ever-present on the stage sitting at Harry's pub, overly keen on hearing stories of hanging, and voicing their support for capital punishment. An old man among these cronies named Arthur treats Harry Allen and Albert Pierrepoint as public heroes, which is a representation of the amount of support and admiration the hangmen received from the public at the time of the abolition. As the iconic status of hangmen among the commoners is observed in Arthur's own words: “. . . if hangman's gone off I might go. I don't even like the pints here, but they've a hangman" (McDonagh, 2015, p. 28). Along with the proud assertions of Harry about his profession, the cronies' blind support of capital punishment constitutes another dark comedy element of the play. Besides the two illogical hangmen, McDonagh also portrays the problematic aspects of capital punishment through a presentation of a group of people who glorify executioners in the country. Apparently, the attitude of Harry's customers also mirrors the real response of common people to the idea of capital punishment at the time. As it is reported in Manchester Evening News, "[real hangman] Harry had the regulars hanging on his every 
word" in his pub (Cunliffe and Gwilliam, 2006, para. 8). Evidently, he was popular among the people of his town, and the public supported his profession. McDonagh represents this account with the curious attitude of the cronies as they sit at Harry's pub all the time and watch the comers and goers. This can be linked to Lawrence Friedman's concept of "lexitainment," which corresponds to viewing "legal process as theater and entertainment" (2000, p. 539). Instead of discussing the serious influences of this practice on human beings and its function in terms of the exercise of justice, the customers treat such matters as a form of entertainment. Friedman lists three aspects of how legal processes might be viewed by the public as didactic, instrumental, and as pure entertainment (2000, p. 539). From the attitudes of Harry's cronies in the play, it is seen that public hanging is far from acting as any deterrent factor among community members as most of them consider it as fun. McDonagh's presentation of ignorant commoners posits an alternative view that death penalty is more likely to be seen as a case of amusement by society than as a restraining force. This also indicates McDonagh's critical view of capital punishment whose practicality to eradicate crime is disputed in the play.

Political aspects of McDonagh's play could also be linked to the contemporary period as discussions of capital punishment started again in recent years. Interestingly enough, he chooses such a topic in 2015 when death penalty has long been abolished in Britain and there is almost no possibility of it being reintroduced. However, it should be noted that debates over capital punishment never really stopped in the country. According to Neville Twitchell's research, "[i]t is an issue that never goes away, no matter how much abolition seems now to have receded into the mists of time. It remains the most contentious of all of the 'peripheral' question of British politics" (2009, p. 9). Like its popularity, support for capital punishment also did not really cease in the country. It is known that following the abolition of death penalty until 1994, "[t] here were thirteen attempts to restore capital punishment" (Davies, 2007, p. 253) though they have all been either suspended or cancelled altogether. Despite the widely-accepted opinion that death penalty does not act as a deterrent or as retribution, criminal punishment has often been supported for severe crimes as in the cases of terrorists and child abusers. Patrick Lonergan claims that "[f]ifty years after capital punishment was abolished in the UK, survey after survey shows that a majority of voters here favour its re-introduction, especially for such offences as child abuse or terrorism" (2015, p. 19). At a time in which such crimes are at an uncontrollable increase, death penalty comes up as a popular topic for discussion among society members and politicians. The Conservatives have mostly been prohanging, and as recent as 2018 John Hayes, a Conservative MP "asked the justice secretary to 'make an assessment of the potential merits of bringing forward legislative proposals to reintroduce the death penalty to tackle violent crime"" (Kentish, 2018, para. 5). The increase in such crime rates also causes an increase in public support concerning the reintroduction of death penalty. In 2011, an Angus Reid Public Opinion poll found that "[a] majority of people in Great Britain would welcome the reinstatement of the death penalty, and more than half regard it as a more suitable punishment for murderers than life imprisonment" (Canseco, 2011, para. 1). The most recent discussion over the issue of capital punishment in British Parliament took place in 2013 when "[a] bill to allow for capital punishment for certain offences was introduced" (Capital Punishment Bill, 2013), which was eventually withdrawn. Concerning the recent arguments about the reintroduction of death penalty in the twenty-first century, McDonagh initiates a discussion about the legitimation of state violence through a depiction of the history of hanging. All cases of execution mentioned in Hangmen are either accidental or unlawful, and they all demonstrate the failure of the justice system. Therefore, McDonagh's play also provides a warning note to the contemporary society as it displays the former problematic uses of execution that are against human rights. 
To conclude the argument about McDonagh's political involvement with his topical play Hangmen, it needs to be stated that this play poses a stronger political stance when considered in relation to the actual context concerning the issue of death sentence in Britain. This play sufficiently proves McDonagh's involvement with the political issues of his day and his past. Also, with the use of a small town in England as the setting of the play, McDonagh indicates his interest in more global affairs. Without leaving aside his style of comedy and peculiar presentation of violence, he makes a point about a serious issue, draws public attention to issues of capital punishment, legalisation of institutional violence and justice system. Apparently, the play manifests the vanity of killing people in the name of justice by way of historicisation and also makes a strong comment about the slippery ground on which human rights sit in the present.

\section{References}

Billington, M. (2015, Sep. 21). Hangmen review - Martin McDonagh returns with a savagely black comedy. The Guardian. Retrieved 21 Nov. 2019 from

https://www.theguardian.com/stage/2015/sep/21/hangmen-review-martin-mcdonaghsprodigal-playful-talent-royal-court-theatre

Campbell, D. (2015). A hanging offence. Hangmen. pp. 14-17. London: Wyndham's Theatre.

Canseco, M. (2011). Death penalty: Most Britons support reinstating the death penalty for murder. Retrieved 20 Apr. 2019 from:

web.archive.org/web/20120819163903/http:/www.angusreid.com/wpcontent/uploads/2 011/08/2011.08.23_Death_BRI.pdf

Capital punishment bill 2013-14. (2013). Retrieved 22 Apr. 2019 from: services.parliament.uk/bills/2013-14/capitalpunishment.html

Cavendish, D. Hangmen, Royal Court, review: 'pitch-perfect.' The Telegraph. Retrieved 21 Nov. 2019 from:

https://www.telegraph.co.uk/theatre/what-to-see/hangmen-royal-court-review/

Clapp, S. (2015, Sep. 27). Hangmen review - a tremendous, terrifying return by Martin McDonagh. The Guardian. Retrieved 21 Nov. 2019 from:

https://www.theguardian.com/culture/2015/sep/27/hangmen-martin-mcdonagh-royalcourt-review-david-morrissey-reece-shearsmith-tremendous-terrifying

Clark, R. (1995a). English hangmen 1850 to 1964. Retrieved 20 Apr. 2019 from: http://www.capitalpunishmentuk.org/hangmen.html

Clark, R. (1995b). James Francis Hanratty: The A6 murder. Retrieved 20 Apr. 2019 from: http://www.capitalpunishmentuk.org/hanratty.html

Cunliffe, H. and Gwilliam, J. (2006, Apr. 6). Harry had the regulars hanging on his every word. Manchester Evening News. Retrieved 19 Apr. 2019 from:

www.manchestereveningnews.co.uk/news/local-news/harry-had-the-regulars-hangingon-his-every-word-1028098.

Davies, C. (2014, Aug. 13). Britain's last executions: Hanging of two jobless criminals a 'low key' affair. The Guardian. Retrieved 19 Apr. 2019 from:

https://www.theguardian.com/world/2014/aug/13/britain-last-executions-hangingcriminals-low-key. 
Davies, C. (2007). The strange death of moral Britain. London: Routledge.

Fielding, S. (2008). Pierrepoint: A family of executioners. London: John Blake.

Friedman, L. M. (2000). Lexitainment: Legal process as theater. DePaul Law Review, 50(2), 539-556.

Kentish, B. (2018, Nov. 3). Tory MP asks government to consider bringing back death penalty. The Independent. Retrieved 20 Apr. 2019 from: https://www.independent.co.uk/news/uk/politics/tory-mp-bring-back-death-penaltyjohn-hayes-lincolnshire-capital-punishment-a8615731.html

Lonergan, P. (2015). A pacifist rage. Hangmen. pp. 19-20. London: Wyndham's Theatre.

McDonagh, M. (2015). Hangmen. London: Faber.

Lowe, N. (2017). Mastering modern British history. London: Palgrave.

O'Hagan, S. (2015, Sep. 13). Martin McDonagh interview: Theatre is never going to be edgy in the way I want it to be. The Guardian. Retrieved 21 Apr. 2019 from: www.theguardian.com/culture/2015/sep/11/martin-mcdonagh-theatre-never-going-tobe-edgy-hangmen-interview

Pilný, O. (2018). "Did you like how I made that turn officer?” Martin McDonagh's Hangmen and capital punishment. Boundaries, Passages, Transitions, 8, 91-100.

Pilný, O. (2017). "Fun, disturbing and ultimately forgettable?" Notes on the Royal Court Theatre production of Martin McDonagh's Hangmen. HJEAS, 23(1), 121-126.

Seal, L. (2014). Capital punishment in twentieth-century Britain: Audience, justice, memory. London: Routledge.

Tomlinson, A. (2006). Capital punishment in Great Britain: Theories concerning abolition. Historia, 15, 20-30.

Twitchell, N. H (2009). The politics of the rope: The campaign to abolish capital punishment in Britain 1955-1969 (Doctoral dissertation). London Metropolitan University, London, UK.

Wade, S. (2009). Britain's most notorious hangmen. Barnsley: Wharncliffe.

Wright, T. J. (2014). A barbarous penalty which the community has no right to exact: Why capital punishment was abolished in Britain, 1947-69 (Doctoral dissertation). University of York, York, UK. 